\title{
Arbuscular Mycorrhizal Fungus Inoculation on Antioxidant Enzyme Activities in Maize Plants at Different Levels of Fe and Zn Fertilization
}

\author{
Natarajan Balakrishnan $^{1 *}$ and Kizhareal S. Subramanian ${ }^{2}$ \\ ${ }^{1}$ Department of Soil Science and Agricultural Chemistry, Tamil Nadu Agricultural University, \\ Coimbatore 641 003, Tamil Nadu, India \\ ${ }^{2}$ Department of Nano Science and Technology, Tamil Nadu Agricultural University, \\ Coimbatore 641 003, Tamil Nadu, India \\ *Corresponding author
}

\begin{tabular}{|c|c|}
\hline & A B S T R A C T \\
\hline & \multirow{6}{*}{$\begin{array}{l}\text { Greenhouse and field experiments were conducted to study the changes of antioxidant } \\
\text { enzyme activities of arbuscular mycorrhizal (AM) fungus Glomus intraradices Schenck } \\
\text { and Smith inoculated (M+) and non-inoculated (M-) maize (Zea mays L.) plants (variety } \\
\text { COHM5) under varying levels of zinc }\left(12.5 \text { and } 25 \mathrm{~kg} \mathrm{ha}^{-1}\right) \text { iron }\left(12.5 \text { and } 25 \mathrm{~kg} \mathrm{ha}^{-1}\right) \text {. } \\
\text { Roots and shoots sampled at } 45 \text { and } 75 \text { days after sowing (DAS) were estimated for its } \\
\text { antioxidant enzymes superoxide dismutase, peroxidase, IAA oxidase, polyphenol oxidase, } \\
\text { acid phosphatase and nutritional status especially Fe and Zn concentrations. Mycorrhizal } \\
\text { inoculation significantly }(P \leq 0.01) \text { increased all the antioxidant enzymes in both roots and } \\
\text { shoots at } 45 \text { and } 75 \text { DAS regardless of Fe and } \mathrm{Zn} \text { levels. All enzyme activities except SOD } \\
\text { increased progressively with increasing levels of Fe and Zn under M+ and M- conditions. } \\
\text { Acid phosphatase activity in M+ roots and shoots were higher in all levels of Zn and Fe } \\
\text { but the values decreased with increasing levels of Zn particularly in roots. Mycorrhizal } \\
\text { fungus inoculated plants had higher Fe and Zn concentrations in both stages in comparison } \\
\text { to non-inoculated plants. Overall, data suggest that mycorrhizal symbiosis plays a vital } \\
\text { role in enhancing activities of antioxidant enzymes and nutritional status that enables the } \\
\text { host plant to sustain zinc and iron deficient conditions. }\end{array}$} \\
\hline Keywords & \\
\hline $\begin{array}{l}\text { Arbuscular } \\
\text { mycorrhiza, } \\
\text { Iron, Zinc, Maize, } \\
\text { Antioxidant } \\
\text { enzymes, Nutrition }\end{array}$ & \\
\hline Article Info & \\
\hline $\begin{array}{l}\text { Accepted: } \\
\text { 23 May } 2017 \\
\text { Available Online: } \\
\text { 10 June } 2017\end{array}$ & \\
\hline & \\
\hline
\end{tabular}

\section{Introduction}

Zinc is an essential mineral nutrient and a cofactor of over 300 enzymes and proteins involved in cell division, nucleic acid metabolism and protein synthesis (Marschner, 1986). Zinc deficient soils can be easily treated with zinc fertilizers to provide an adequate supply of zinc to crops. When the supply of plant - available zinc is inadequate, crop yield is reduced and the quality of crop products is frequently impaired. In plants, Zinc plays a key role as a structural constituent or regulatory co-factor of a wide range of different enzymes and plant species are affected by zinc deficiency on a wide range of soil types in most agricultural regions of the world. Activated oxygen species (AOS), such as superoxide $\left(\mathrm{O}_{2}^{-}\right)$, hydrogen peroxide $\left(\mathrm{H}_{2} \mathrm{O}_{2}\right)$, and hydroxyl radicals $\left(\mathrm{OH}^{-}\right)$, are formed as by-products of normal metabolism in different cellular organelles (Scandalios 1993). A number of studies have clearly shown that $\mathrm{Zn}$ uptake via mycorrhizae is important for the alleviation of $\mathrm{Zn}$ deficiency in several plant species (Evans 
and Miller, 1988; Sylvia et al., 1993). These literatures suggest that there is a possibility of using mycorrhiza as a biological agent to alleviate $\mathrm{Zn}$ deficiencies in crops.

Arbuscular mycorrhizal (AM) fungi can colonize the roots of most vascular plants and can develop a complex system of extraradical hyphae under natural conditions. AM fungi can initiate a defense - like response when colonizing some host roots (Morandi et al., 1984). Mycorrhizae may help plants to thrive in Mediterranean semi-arid ecosystems, where the water deficit seriously limits plant growth, by altering antioxidant enzyme activities (Requena et al., 2001). The effect of mycorrhizal inoculation on SOD isozymes in mycorrhizal roots of red clover (Palma et al., 1993) and Pisum sativum L. (Arines et al., 1994) plants and on the SOD activity in shoots of mycorrhizal Lactuca sativa L. plants (Ruiz-Lozano et al., 1996). The activity levels of some antioxidant enzymes have been investigated in roots and nodules of mycorrhizal soybean plants (Porcel et al., 2003).

The oxidative stress involves many physiological and biochemical changes (Magnoli et al., 1999) during root infection changes in enzyme activities and damage to membrane permeability. AM are known to enhance plant uptake of phosphate $(\mathrm{P})$ and other mineral nutrients under certain conditions (Abbott and Robson, 1984). The effects of $\mathrm{P}$ and micro-nutrient levels on development of an arbuscular mycorrhizal fungus (AMF) and uptake of $\mathrm{Zn}, \mathrm{Cu}, \mathrm{Mn}$ and $\mathrm{Fe}$ by maize (Zea mays L.) (Faber et al., 1990). Phosphatases are important for $P$ nutrition of plants especially when there is storage of inorganic $\mathrm{P}$ in the soil. Phosphatase activity in the rhizosphere or soil solution may originate from plant roots (Tarafdar and Jungk, 1987; Dinkelaker and Marschner, 1992). The plant - mycorrhizal fungus symbiosis results from a number of changes in gene expression, metabolism and morphogenesis (Bonfante and perotto 1995).

We hypothesized that mycorrhizal colonization to promote physiological changes in host plants by increasing plant metabolic changes and antioxidant enzyme activities. To test this hypothesis, we examined antioxidant enzymes such as SOD, CAT, CAase, peroxidase, polyphenol oxidase, and IAA oxidase, acid phosphatase and nutritional status in roots and shoots of inoculated and non-inoculated maize plants exposed to varying levels of $\mathrm{Zn}$. The progressive physiological changes in host plant were assessed at 45 and 75 days after sowing.

\section{Materials and Methods}

\section{Experimental Soil}

Field experiments were conducted in two locations one each at the Experimental Farms of Agricultural Research Station (ARS), Bhavanisagar and Tamil Nadu Agricultural University (TNAU), Coimbatore, under natural conditions. In the same two locations, soil samples were collected, processed and autoclaved in order to eliminate the indigenous mycorrhizal fungal population. Simultaneously, greenhouse experiments were undertaken in the sterilized soils. The calcareous soil was an Inceptisol, sandy loam in texture, alkaline in $\mathrm{pH}$ (8.4), free from salinity $\left(0.34 \mathrm{~d} \mathrm{Sm}^{-1}\right)$ and carried low organic carbon status (3.2 $\left.\mathrm{g} \mathrm{kg}^{-1}\right)$, available $\mathrm{N}$ $\left(220.4 \mathrm{~kg} \mathrm{ha}^{-1}\right)$ and available $\left(\mathrm{NaHCO}_{3}{ }^{-}\right.$ extractable) $\mathrm{P}\left(9.6 \mathrm{~kg} \mathrm{ha}^{-1}\right)$ and is medium in available $\mathrm{K}\left(224 \mathrm{~kg} \mathrm{ha}{ }^{-1}\right)$. The soil had extremely low status of available (Diethylene Triamine Penta Acetic Acid-extractable) $\mathrm{Zn}$ $\left(0.63 \mathrm{mg} \mathrm{kg}^{-1}\right)$ and $\mathrm{Fe}\left(0.86 \mathrm{mg} \mathrm{kg}^{-1}\right)$. The experimental soil of non-calcareous was an Alfisol, sandy loam in texture, neutral in $\mathrm{pH}$ 
(7.4), free from salinity $\left(0.04 \mathrm{dSm}^{-1}\right)$ and it carried low organic carbon status $(0.4 \%)$, available $\mathrm{N}\left(1.23 \mathrm{~g} \mathrm{~kg}^{-1}\right)$, available $\left(\mathrm{NaHCO}_{3}-\right.$ extractable $) \mathrm{P}\left(0.058 \mathrm{~g} \mathrm{~kg}^{-1}\right)$ and medium in available $\mathrm{K}\left(1.6 \mathrm{~g} \mathrm{~kg}^{-1}\right)$. The soil had extremely low status of available (DTPA extractable) Zn $\left(0.63 \mathrm{mg} \mathrm{kg}^{-1}\right)$. And high in available $\mathrm{Fe}(36.2$ $\left.\mathrm{mg} \mathrm{kg}^{-1}\right)$

Both field tests and greenhouse experiments had the same set of treatments. Treatments consisted of two levels of $\mathrm{FeSO}_{4}$ (12.5 and 25 $\mathrm{kg} \mathrm{ha}^{-1}$ ) and two levels of $\mathrm{ZnSO}_{4}$ (12.5 and 25 $\mathrm{kg} \mathrm{h} \mathrm{h}^{-1}$ ) in the presence or absence of arbuscular mycorrhizal fungal (AMF) inoculation. There were 8 treatment combinations replicated four times in a factorial randomized block design (FRBD). The AMF inoculum carrying Glomus intraradices $(2 \mathrm{~g})$ was applied at the base of the seed hole just prior to sowing. Vermiculite based mycorrhizal inoculums (Glomus intraradices TNAU-11-08) used in this study was provided by the Department of Microbiology of this university. This strain was cultured in maize plants and propagules comprised of infected root bits and spores were blended in sterile vermiculite. Maize hybrid seeds (COMH-5) was sown on the inoculum layer of soil. Germination percentage was nearly $95 \%$ on the seventh day of sowing. Half the dose of $\mathrm{N}(100 \mathrm{~kg}$ ha $\left.{ }^{1}\right)$ and full dose of $\mathrm{P}\left(100 \mathrm{~kg} \mathrm{ha}^{-1}\right)$ and $\mathrm{K}(100$ $\mathrm{kg} \mathrm{ha}^{-1}$ ) were applied in the form of urea, single superphosphate and muriate of potash, respectively, as basal at the time of sowing. In addition, two levels of $\mathrm{Fe}$ as $\mathrm{FeSO}_{4}$ and $\mathrm{Zn}$ as $\mathrm{ZnSO}_{4}$ were applied as per treatment. In all the four experiments, root colonization, plant chlorophyll content, biochemical and physiological changes were recorded at 45 and 75 DAS.

\section{Chlorophyll}

Fresh leaf samples $(250 \mathrm{mg})$ were macerated in a pestle and mortar with $10 \mathrm{~mL}$ of $80 \%$ acetone and centrifuged at $5000 \mathrm{rpm}$ for 10 min. The supernatant was collected and the volume was made up to $25 \mathrm{~mL}$ using $80 \%$ acetone and the chlorophyll content was obtained by measuring the OD at $663 \mathrm{~nm}$ in a spectrophotometer (Varian Cary 50 UVvisible spectrophotometer) (Bruinsma, 1963). The chlorophyll content of samples was expressed as $\mathrm{mg} \mathrm{g}^{-1}$ of fresh leaves.

\section{Soluble proteins}

Soluble proteins in shoots were determined by the Folin phenol method (Lowry et al., 1951) using bovine serum albumin (BSA) as a standard. $250 \mathrm{mg}$ of root or leaf tissue were macerated with $10 \mathrm{~mL} 0.2 \mathrm{M}$ phosphate buffer and centrifuged at $3000 \mathrm{rpm}$ for 10 min. One $\mathrm{mL}$ of supernatant solution was mixed with $5 \mathrm{~mL}$ alkaline copper tartarate reagent $\left(2 \% \mathrm{Na}_{2} \mathrm{CO}_{3}\right.$ in $0.1 \mathrm{~N} \mathrm{NaOH}$ and $0.5 \% \mathrm{CuSO}_{4}$ in $1 \%$ sodium potassium tartarate mixed in 50:1) and kept for $30 \mathrm{~min}$ for the biuret reaction to take place. Soluble proteins content was estimated by measuring the absorbance of blue colour that developed with Folin Ciocalteau reagent (1 part of Folin Ciocalteau reagent mixed with 2 parts of distilled water) at $660 \mathrm{~nm}$ in spectrophotometer (Varian Cary 50 UVvisible spectrophotometer). The soluble proteins content was expressed as $\mathrm{mg} \mathrm{g}^{-1}$.

\section{Total Phenols}

Fresh shoots $(500 \mathrm{mg})$ were macerated in a pestle and mortar with $10 \mathrm{ml}$ of $80 \%$ ethanol and centrifuged at $10,000 \mathrm{rpm}$ for $10 \mathrm{~min}$. The supernatant solution was evaporated to a dry powder and homogenized in $2.5 \mathrm{ml}$ of distilled $\mathrm{H}_{2} \mathrm{O}$ and mixed in $0.5 \mathrm{ml}$ FolinCiocalteau reagent. After 3 min of incubation, $2 \mathrm{ml}$ of $20 \%$ (w/v) $\mathrm{Na}_{2} \mathrm{CO}_{3}$ was added and kept in boiling water for $1 \mathrm{~min}$ and cooled to room temperature. Then the absorbance was read at $650 \mathrm{~nm}$ and was compared with the standard curve prepared using catechol. 


\section{Peroxidase activity}

Fresh shoots of $500 \mathrm{mg}$ were macerated with $0.1 \mathrm{M}$ phosphate buffer, $\mathrm{pH}$ 7.0, in a pre-chilled pestle and mortar at $4{ }^{\circ} \mathrm{C}$. The homogenate was centrifuged at 5,000 rpm for 15 minutes. One $\mathrm{ml}$ of supernatant solution was taken for assay and mixed with $3 \mathrm{ml}$ of $0.05 \mathrm{M}$ pyrogallol and $0.5 \mathrm{ml} \mathrm{30 \%} \mathrm{hydrogen} \mathrm{peroxide.} \mathrm{The} \mathrm{change} \mathrm{in}$ absorbance was measured at $425 \mathrm{~nm}$ in 30 seconds interval up to 120 seconds and the enzyme activity was reported as change in OD $\min ^{-1} \mathrm{~g}^{-1}$ of sample. Reaction mixture containing pyrogallol and hydrogen peroxide without enzyme extract constituted the blank (Sadasivam and Manickam, 1996).

\section{IAA oxidase}

IAA oxidase activity was measured as $\mathrm{mg}$ of unoxidised auxin in the fresh samples as suggested (Sadasivam and Manickam, 1996). Fresh shoots of $500 \mathrm{mg}$ were macerated with $0.1 \mathrm{M}$ phosphate buffer, $\mathrm{pH} 7.0$, in a prechilled pestle and mortar at $4^{\circ} \mathrm{C}$. The homogenate was centrifuged at 5,000 rpm for $15 \mathrm{~min}$. One $\mathrm{ml}$ of supernatant was taken for assay and mixed with $1 \mathrm{ml}$ of extraction buffer ( $0.1 \mathrm{M}$ phosphate buffer) and $1 \mathrm{ml}$ of 10 ppm auxin solution. The mixture was kept in dark for $1 \mathrm{hr}$ and added with $8 \mathrm{ml}$ of GardenWeber reagent and the absorbance was measured at $540 \mathrm{~nm}$ and compared with standard curve prepared using auxin solution of 20 to $100 \mathrm{ppm}$.

\section{Acid phosphatase}

The acid phosphatase activity was measured as described by Dodd et al., (1987). Freeze dried shoots $(100 \mathrm{mg})$ were ground in prechilled pestle and mortar with $10 \mathrm{ml}$ of $0.2 \mathrm{M}$ sodium acetate buffer ( $\mathrm{pH}$ 5.0). The enzyme extract was centrifuged at $5000 \mathrm{rpm}$ for 15 minutes. Supernatant enzyme extract of 0.1 $\mathrm{ml}$ was incubated for 5 minutes with assay mixture containing $0.4 \mathrm{ml}$ of $10 \mathrm{mM} \rho$ nitrophenol phosphate and $0.5 \mathrm{ml}$ of extraction buffer. The reaction was terminated by the addition of $2 \mathrm{ml} 200 \mathrm{mM} \mathrm{Na}_{2} \mathrm{CO}_{3}$. The resultant yellow chromophore was measured at $405 \mathrm{~nm}$ in a spectrophotometer. Acid phosphatase activity was expressed as the amount of $\rho$-nitrophenol produced per gram of tissue in one hour.

\section{Superoxide dismutase}

Fresh shoots of $500 \mathrm{mg}$ was macerated with $10 \mathrm{ml} 0.2 \mathrm{M}$ citrate phosphate buffer ( $\mathrm{pH}$ 6.5) at $4^{\circ} \mathrm{C}$. The homogenate was centrifuged at $10,000 \mathrm{rpm}$ for 30 minutes. The SOD activity in the supernatant was determined by its ability to inhibit the photochemical reduction of nitro blue tetrazolium (NBT) as suggested by Beyer and Fridovich (1987). One $\mathrm{ml}$ of supernatant was mixed with $3 \mathrm{ml}$ assay mixture $(50 \mathrm{mM}$ sodium phosphate buffer, 13 $\mathrm{mM}$ methionine, $75 \mu \mathrm{M}$ NBT and $0.1 \mathrm{mM}$ EDTA) in a test tube. At the end, $2 \mu \mathrm{M}$ riboflavin $(0.01 \mathrm{ml})$ was added and mixed thoroughly. The tubes were illuminated for 7 minutes in an aluminum foil lined box containing fluorescent lamps. Blank was run without enzyme extract. The change in absorbance was measured at $560 \mathrm{~nm}$. The decrease in NBT reduction was calculated from the blank and sample absorbance values and $50 \%$ decrease in NBT reduction was reported as 1 unit of SOD.

\section{Catalase activity}

Catalase activity of leaf was estimated according to Woodbury et al., (1971) and expressed as $\mu \mathrm{g} \mathrm{H}_{2} \mathrm{O}_{2}$ reduced $\min ^{-1} \mathrm{~g}^{-1}$ fresh weight. Fresh shoots of $500 \mathrm{mg}$ of leaf sample were macerated with $10 \mathrm{ml}$ of phosphate buffer. The content was Centrifuge at 3000 $\mathrm{rpm}$ for 10 minutes. $1 \mathrm{ml}$ of each supernatant was taken in 5 beakers. To this $5 \mathrm{ml}$ of $1.5 \%$ sodium perborate and $1.5 \mathrm{ml}$ of phosphate 
buffer was added. Later $10 \mathrm{ml}$ of $2 \mathrm{~N}$ sulphuric acids at the time interval of 1 minute, 2 minute, 3 minute, and 4 minutes was added after enzyme extract in first four beakers respectively being added. In the final beaker, $10 \mathrm{ml}$ of sulphuric acid was added before addition of enzyme extract. This beaker was kept as blank for comparison. The content in the beaker was titrated against $0.05 \mathrm{~N}$ $\mathrm{KMnO}_{4}$. The end point was development of pink colour which persisted for 30 seconds. The volume of $\mathrm{KMnO}_{4}$ consumed was noted.

\section{Carbonic anhydrase}

Carbonic anhydrase (CA) was estimated by the method of Gibson and Leece (1981). CA was extracted from triplicate $500 \mathrm{mg}$ samples of fresh leaf tissue with $5 \mathrm{ml} 100 \mathrm{mM}$ Tris$\mathrm{SO}_{4} \mathrm{pH}$ 8.3, containing I mM EDTA and 100 $\mathrm{mM}$ 2-morcaptoethanol, using a chilled mortar and pestle. Acid washed sand (1 g) was added to aid grinding.

The extract was filtered through moist Miracloth, and the carbonic anhydrase activity of $0.1 \mathrm{ml}$ was measured at $0^{\circ} \mathrm{C}$ by the veronal -indicator method. Extracts with a reaction time of less than 10 seconds were diluted with extraction buffer and reassayed. Controls, which consisted of $0.1 \mathrm{ml}$ buffer in place of enzyme extract, generally completed reaction in 100-110 seconds. Each extract was assayed three times.

Extracts with a reaction time of less than 10 seconds were diluted with extraction buffer and reassayed. Controls, which consisted of $0.1 \mathrm{ml}$ buffer in place of enzyme extract, generally completed reaction in 100-110 seconds. Each extract was assayed three times. Carbonic anhydrase activity was expressed on a fresh weight basis using the formula: $\mathrm{EU} / \mathrm{g}=[10(\mathrm{~Tb}-\mathrm{Te})-1] / \mathrm{g}$, where $\mathrm{Tb}=$ time for the uncatalyzed reaction and $\mathrm{Te}=$ time for the catalyzed reaction

\section{Plant nutrient status}

Maize shoots sampled at 45 and 75 DAS for nutrient analysis were washed thoroughly, dried at $70^{\circ} \mathrm{C}$, weighed and digested in triple acid mixture (9:2:1 nitric: sulphuric: perchloric acid) in a conical flask under a fumehood. The digested samples were diluted to $50 \mathrm{ml}$ with distilled water. Phosphorus concentration of plant tissues was estimated using vanadomolybdo phosphoric acid yellow colour method. Zinc concentrations were measured in the diluted plant extract directly in an atomic absorption spectrophotometer (Varian Spectra AA 220, Australia).

\section{Statistical analysis}

A two-way analysis of variance (ANOVA) was done for all data and comparisons among means were made using DMRT (Duncan's Multiple Regression Test) test, calculated at PI0.05. Statistical procedures were carried out with the software package IRRI stat (IRRI, Manila Philippines).

\section{Results and Discussion}

\section{Chlorophyll}

Mycorrhizal plants $(\mathrm{M}+)$ had significantly higher concentration of chlorophyll at both soils under sterilized and natural conditions over uninoculated plants (Table 1). Fe and $\mathrm{Zn}$ levels produced a significant difference in chlorophyll concentration

\section{Soluble proteins}

The soluble proteins $\mathrm{M}+$ shoots was significantly $(P \leq 0.01)$ higher than $\mathrm{M}$ - shoots and the increase was exhibited in all the levels of $\mathrm{Fe}$ and $\mathrm{Zn}$ levels at both stages in calcareous and non-calcareous soil under sterilized (calcareous M- 45.5; M+ 51.4, non-calcareous M- 50.3; $\mathrm{M}+54.6 \mathrm{mg} \mathrm{g}^{-1}$ ) and natural 
(calcareous M- 46.1; M+ 56.4, non-calcareous M- 43.1; M+ $52.7 \mathrm{mg} \mathrm{g}^{-1}$ ) conditions (Table $1)$. With the progression of growth, both $\mathrm{M}$ and $\mathrm{M}+$ plants had higher soluble proteins in shoots in both calcareous and non-calcareous soil under sterilized condition.

\section{Total phenols}

Mycorrhizal plants registered significantly ( $P$ $\leq 0.01)$ higher phenol concentration than the un-inoculated plants irrespective of the Fe and Zn levels (Table 2). Mycorrhizal inoculation resulted in the improving the total phenol concentration in soil by 27.8 and $37.0 \%$ in calcareous soil of both sterilized and natural conditions and 34.8 and $46.7 \%$ in noncalcareous soil of either sterilized or natural conditions at 45 DAS in comparison to $\mathrm{M}$ plants.

\section{Acid phosphatase activity}

Acid phosphatase activity of $\mathrm{M}+$ shoots was significantly $(P \leq 0.01)$ higher than the uninoculated maize plants irrespective of the $\mathrm{Fe}$ and $\mathrm{Zn}$ levels (Table 2). Mycorrhizal inoculation resulted in the increasing the acid phosphatase activity of maize plants by 13.4 and $9.1 \%$ in calcareous soil of both sterilized and natural conditions and 11.7 and $8.3 \%$ in non-calcareous soil of sterilized and natural conditions.

\section{Peroxidase (POX) activities}

Mycorrhiza inoculation increased the POX activities in maize plant shoots significantly $(P \leq 0.01)$ higher than the uninoculated maize plants irrespective of the $\mathrm{Fe}$ and $\mathrm{Zn}$ levels (Fig.1a. Application of $\mathrm{Fe}$ and $\mathrm{Zn}$ also significantly increased the POX activities at both stages in calcareous and non-calcareous soil. A significantly higher POX activity in maize plants was recorded by $\mathrm{Fe}_{25} \mathrm{Zn}_{25}$ followed by $\mathrm{Fe}_{12.5}$ $\mathrm{Zn}_{25}$ whereas lowest recorded in $\mathrm{Fe}_{12.5} \mathrm{Zn}_{12.5}$ at both soils of sterilized and natural condition and both stages.

\section{Poly phenol oxidase (PPO) activities}

The PPO activities in M+ shoots was significantly $(P \leq 0.01)$ higher than $\mathrm{M}$ - plants and the increase was exhibited in all the levels of $\mathrm{Fe}$ and $\mathrm{Zn}$ in calcareous and noncalcareous soil under sterilized and natural conditions (Table 3 ). With the progression of growth, both $\mathrm{M}-$ and $\mathrm{M}+$ plants had higher PPO activity of both calcareous and noncalcareous soil under sterilized or natural conditions.

\section{Indole acetic acid (IAA) oxidase activities}

Mycorrhizal shoots significantly $(P \leq 0.01)$ had higher IAA oxidase than $M$ - plants irrespective of the $\mathrm{Fe}$ and $\mathrm{Zn}$ levels at both stages in calcareous and non-calcareous soil under sterilized (calcareous M- 173.0; M+ 187.7 Change in OD/min/g, non-calcareous M- 167.1; M+ 188.7 Change in OD/min/g) and natural (calcareous M- 162.2; M+ 181.0 Change in $\mathrm{OD} / \mathrm{min} / \mathrm{g}$, non-calcareous $\mathrm{M}$ 167.1; M+ 198.9 Change in $\mathrm{OD} / \mathrm{min} / \mathrm{g}$ ) condition (Table 3). Application of Fe and $\mathrm{Zn}$ fertilizers also significantly increased the IAA oxidase activities at both stages in crop under sterilized and natural condition.

\section{Super oxide dismutase (SOD)}

The SOD activity in M+ shoots was significantly $(P \leq 0.01)$ higher than $\mathrm{M}$ - shoots and the increase was exhibited in all the levels of $\mathrm{Fe}$ and $\mathrm{Zn}$ at both stages in calcareous and non-calcareous soil under sterilized (calcareous M- 76.8; M+ 97.3, non-calcareous M- 98.4; M+ $109.6 \mathrm{U} \mathrm{g}^{-}$ ${ }^{1}$ ) and natural (calcareous $\mathrm{M}-129.6 ; \mathrm{M}+$ 141.7, non-calcareous M- 124.5; M+ 130.9 U $\mathrm{g}^{-1}$ ) conditions and interactions was significant in sterilized and natural condition (Table 3). With the progression of growth, both $\mathrm{M}$ - and 
M+ plants had higher SOD activity in both calcareous and non-calcareous soil under sterilized or natural conditions.

\section{Catalase activity (CAT)}

Mycorrhizal inoculated plants recorded significantly $(P \leq 0.01)$ higher catalase activity than the uninoculated irrespective of the $\mathrm{Fe}$ and $\mathrm{Zn}$ levels at both stages in calcareous and non- calcareous soil under sterilized and natural conditions and the interactions were not significant (Table 4). Mycorrhizal inoculation resulted in the improving the catalase activity in plants by 14.5 and $7.9 \%$ in calcareous soil of both sterilized and natural conditions and 16.9 and $8.2 \%$ in non-calcareous soil of either sterilized or natural conditions at 45 DAS in comparison to M- soil.

Fig.1 Peroxidase activity (a), shoot $\mathrm{Zn}(\mathrm{b})$ and $\mathrm{Fe}$ (b) content $\left(\mathrm{mg} \mathrm{kg}^{-1}\right)$ of arbuscular mycorrhizal fungus inoculated (AMF+) (filled bars) and uninoculated (AMF-) (Empty bars) maize plants $(\mathrm{n}=3)$ under two levels of $\mathrm{Fe}\left(12.5\right.$ and $\left.25 \mathrm{~kg} \mathrm{FeSO}_{4} \mathrm{ha}^{-1}\right)$ and two levels of $\mathrm{Zn}(12.5 \mathrm{And} 25 \mathrm{~kg}$ $\mathrm{ZnSO}_{4} \mathrm{ha}^{-1}$ ) in soils. Error bars represent standard errors of three replications

(a)

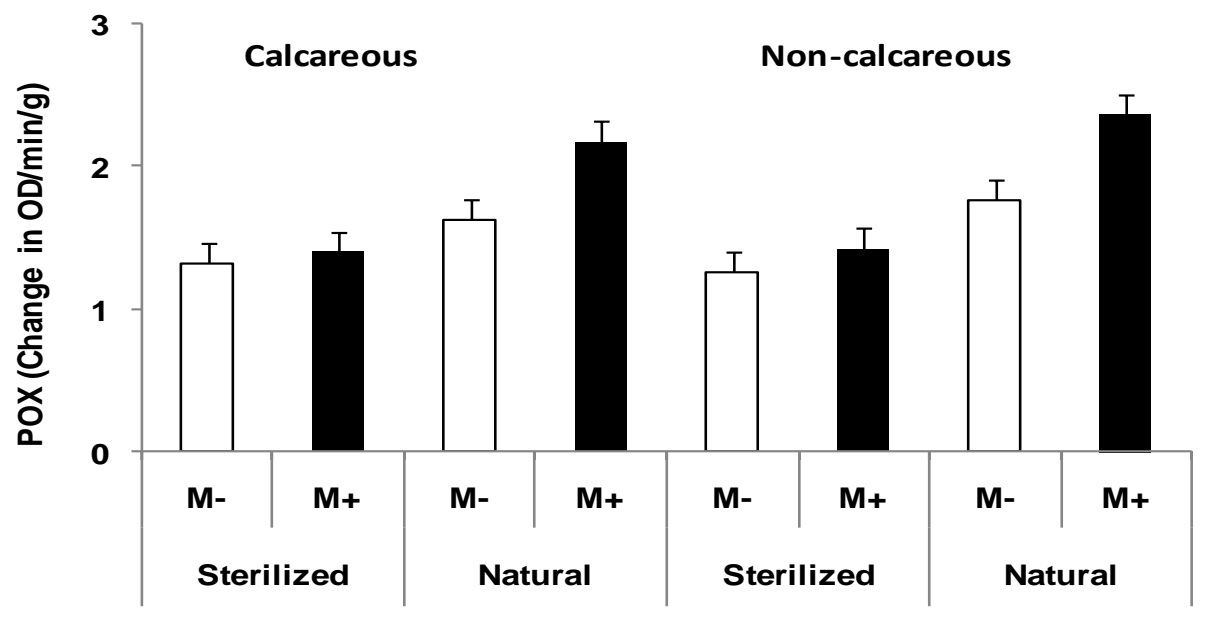

(b)

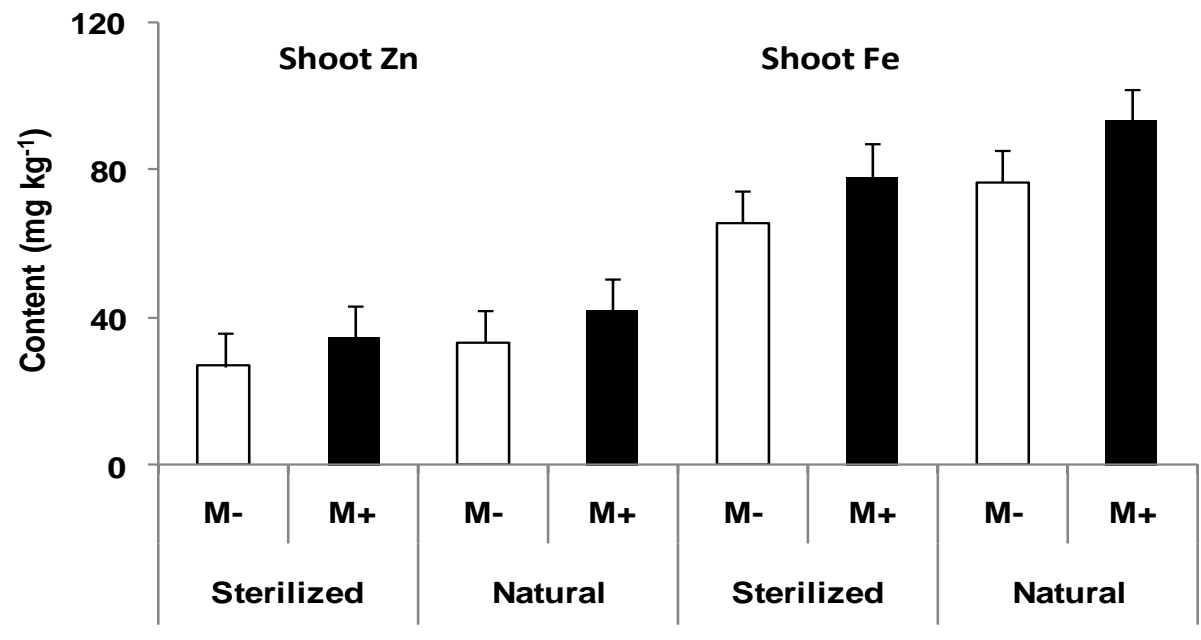


Table.1 Total chlorophyll and soluble protein concentrations examined in the shoots of arbuscular mycorrhiza inoculated (AMF+) and non-inoculated (AMF-). The levels of significance for ANOVA, $*=P \leq 0.05 ; * *=P \leq 0.01$; NS $=$ Not significant.

Means followed by a common letter are not significantly different at the $5 \%$ level by DMRT

\begin{tabular}{|c|c|c|c|c|c|c|c|c|c|c|c|c|c|c|c|c|}
\hline \multirow{4}{*}{ Treatments } & \multicolumn{8}{|c|}{ Total chlorophyll ( $\mathrm{mg} \mathrm{g}^{-1}$ of tissue) } & \multicolumn{8}{|c|}{ Soluble protein ( $\mathrm{mg} \mathrm{g}^{-1}$ of tissue) } \\
\hline & \multicolumn{4}{|c|}{ Calcareous } & \multicolumn{4}{|c|}{ Non-calcareous } & \multicolumn{4}{|c|}{ Calcareous } & \multicolumn{4}{|c|}{ Non-calcareous } \\
\hline & \multicolumn{2}{|c|}{ Sterilized } & \multicolumn{2}{|c|}{ Natural } & \multicolumn{2}{|c|}{ Sterilized } & \multicolumn{2}{|c|}{ Natural } & \multicolumn{2}{|c|}{ Sterilized } & \multicolumn{2}{|c|}{ Natural } & \multicolumn{2}{|c|}{ Sterilized } & \multicolumn{2}{|c|}{ Natural } \\
\hline & $\mathbf{M}^{-}$ & $\mathbf{M}^{+}$ & $\mathbf{M}^{-}$ & $\mathbf{M}^{+}$ & $\mathbf{M}^{-}$ & $\mathbf{M}^{+}$ & $\mathbf{M}^{-}$ & $\mathbf{M}^{+}$ & $\mathbf{M}^{-}$ & $\mathbf{M}^{+}$ & $\mathbf{M}^{-}$ & $\mathbf{M}^{+}$ & $\mathbf{M}^{-}$ & $\mathbf{M}^{+}$ & $\mathbf{M}^{-}$ & $\mathbf{M}^{+}$ \\
\hline $\mathrm{Fe}_{12.5} \mathrm{Zn}_{12.5}$ & $1.81^{\mathrm{c}}$ & $1.96^{\mathrm{c}}$ & $2.24^{\mathrm{b}}$ & $2.50^{\mathrm{a}}$ & $1.89^{\mathrm{c}}$ & $2.20^{\mathrm{b}}$ & $2.06^{\mathrm{c}}$ & $2.38^{\mathrm{b}}$ & $24.8^{\mathrm{c}}$ & $39.7^{\mathrm{a}}$ & $44.9^{\mathrm{cb}}$ & $47.2^{\mathrm{b}}$ & $45.6^{c}$ & $47.5^{\mathrm{c}}$ & $51.4^{\mathrm{cd}}$ & $65.1^{\mathrm{b}}$ \\
\hline $\mathrm{Fe}_{25} \mathrm{Zn}_{12.5}$ & $1.93^{\mathrm{c}}$ & $2.07^{b}$ & $2.08^{\mathrm{b}}$ & $2.41^{\mathrm{ab}}$ & $2.08^{\mathrm{bc}}$ & $2.16^{\mathrm{b}}$ & $2.35^{\mathrm{b}}$ & $2.44^{\mathrm{b}}$ & $24.7^{\mathrm{c}}$ & $39.4^{\mathrm{a}}$ & $43.5^{\mathrm{cb}}$ & $49.1^{\mathrm{b}}$ & $50.3^{\mathrm{bc}}$ & $52.4^{\mathrm{b}}$ & $53.3^{\mathrm{cd}}$ & $71.2^{\mathrm{a}}$ \\
\hline $\mathbf{F e}_{12.5} \mathbf{Z n}_{25}$ & $2.09^{\mathrm{b}}$ & $2.08^{\mathrm{b}}$ & $2.09^{\mathrm{b}}$ & $2.63^{\mathrm{a}}$ & $2.16^{\mathrm{b}}$ & $2.36^{\mathrm{a}}$ & $2.46^{\mathrm{b}}$ & $2.58^{\mathrm{a}}$ & $39.7^{\mathrm{a}}$ & $40.0^{\mathrm{a}}$ & $47.4^{\mathrm{b}}$ & $57.3^{\mathrm{a}}$ & $51.7^{\mathrm{b}}$ & $58.2^{\mathrm{a}}$ & $53.8^{\mathrm{cd}}$ & $73.4^{\mathrm{a}}$ \\
\hline $\mathrm{Fe}_{25} \mathrm{Zn}_{25}$ & $2.14^{\mathrm{b}}$ & $2.30^{\mathrm{a}}$ & $1.95^{\mathrm{b}}$ & $2.70^{\mathrm{a}}$ & $2.30^{\mathrm{ab}}$ & $2.51^{\mathrm{a}}$ & $2.64^{\mathrm{a}}$ & $2.84^{\mathrm{a}}$ & $35.8^{\mathrm{ab}}$ & $42.0^{\mathrm{a}}$ & $46.3^{\mathrm{b}}$ & $52.1^{\mathrm{ab}}$ & $53.5^{\mathrm{b}}$ & $60.3^{\mathrm{a}}$ & $58.7^{\mathrm{c}}$ & $68.3^{\mathrm{ab}}$ \\
\hline Mean & 1.99 & 2.10 & 2.09 & 2.56 & 2.11 & 2.31 & 2.38 & 2.56 & 31.3 & 40.3 & 45.5 & 51.4 & $\mathbf{5 0 . 3}$ & 54.6 & 54.3 & 69.5 \\
\hline \multicolumn{17}{|c|}{ ANOVA: M (Mycorrhizal inoculation), $\mathbf{F}$ (Fe levels), $\mathbf{Z}$ (Zn levels) } \\
\hline $\mathbf{M}$ & \multicolumn{2}{|c|}{$* *$} & \multicolumn{2}{|c|}{$* *$} & \multicolumn{2}{|c|}{$* *$} & \multicolumn{2}{|c|}{$* *$} & \multicolumn{2}{|c|}{ ** } & \multicolumn{2}{|c|}{$* *$} & \multicolumn{2}{|c|}{$* *$} & \multicolumn{2}{|c|}{ *** } \\
\hline $\mathbf{F}$ & \multicolumn{2}{|c|}{$* *$} & \multicolumn{2}{|c|}{$* *$} & \multicolumn{2}{|c|}{$*$} & \multicolumn{2}{|c|}{$*$} & \multicolumn{2}{|c|}{$*$} & \multicolumn{2}{|c|}{$*$} & \multicolumn{2}{|c|}{$* *$} & \multicolumn{2}{|c|}{$* *$} \\
\hline $\mathbf{Z n}$ & & & & & & * & & $*$ & & & & & & & & \\
\hline $\mathbf{M} \times \mathbf{F}$ & & & & & & * & & * & & & & & & & & \\
\hline $\mathbf{F} \times \mathbf{Z}$ & & & & & & $\mathrm{NS}$ & & IS & & & & & & & & \\
\hline $\mathbf{M} \times \mathbf{Z}$ & & & & & & NS & & $*$ & & & & & & & & \\
\hline $\mathbf{M} \times \mathbf{F} \times \mathbf{Z}$ & & & & & & $\mathrm{NS}$ & & $\mathrm{JS}$ & & & & & & & & \\
\hline
\end{tabular}

Table.2 Total phenols and acid phosphatase activity examined in the shoots of arbuscular mycorrhiza inoculated (AMF+) and noninoculated (AMF-). The levels of significance for ANOVA, $*=P \leq 0.05 ; * *=P \leq 0.01$; NS $=$ Not significant.

Means followed by a common letter are not significantly different at the $5 \%$ level by DMRT

\begin{tabular}{|c|c|c|c|c|c|c|c|c|c|c|c|c|c|c|c|c|}
\hline \multirow{4}{*}{ Treatments } & \multicolumn{8}{|c|}{ Total phenols (\% fresh weight) } & \multicolumn{8}{|c|}{ Acid phosphatase activity $\left(\mu \mathrm{g}\right.$ of $\left.\rho \mathrm{NP} \mathrm{g}^{-1} \min ^{-1}\right)$} \\
\hline & \multicolumn{4}{|c|}{ Calcareous } & \multicolumn{4}{|c|}{ Non-calcareous } & \multicolumn{4}{|c|}{ Calcareous } & \multicolumn{4}{|c|}{ Non-calcareous } \\
\hline & \multicolumn{2}{|c|}{ Sterilized } & \multicolumn{2}{|c|}{ Natural } & \multicolumn{2}{|c|}{ Sterilized } & \multicolumn{2}{|c|}{ Natural } & \multicolumn{2}{|c|}{ Sterilized } & \multicolumn{2}{|c|}{ Natural } & \multicolumn{2}{|c|}{ Sterilized } & \multicolumn{2}{|c|}{ Natural } \\
\hline & $\mathbf{M}^{-}$ & $\mathbf{M}^{+}$ & $\mathbf{M}^{-}$ & $\mathbf{M}^{+}$ & $\mathbf{M}^{-}$ & $\mathbf{M}^{+}$ & $\mathbf{M}^{-}$ & $\mathbf{M}^{+}$ & $\mathbf{M}^{-}$ & $\mathbf{M}^{+}$ & $\mathbf{M}^{-}$ & $\mathbf{M}^{+}$ & $\mathbf{M}^{-}$ & $\mathbf{M}^{+}$ & $\mathbf{M}^{-}$ & $\mathbf{M}^{+}$ \\
\hline $\mathrm{Fe}_{12.5} \mathrm{Zn}_{12.5}$ & $0.10^{\mathrm{cd}}$ & $0.14^{\mathrm{c}}$ & $0.38^{\mathrm{b}}$ & $0.52^{\mathrm{a}}$ & $0.12^{\mathrm{b}}$ & $0.27^{\mathrm{a}}$ & $0.46^{\mathrm{b}}$ & $0.62^{\mathrm{a}}$ & $0.86^{\mathrm{a}}$ & $0.93^{\mathrm{a}}$ & $1.10^{\mathrm{a}}$ & $1.14^{\mathrm{a}}$ & $1.15^{\mathrm{b}}$ & $1.27^{\mathrm{a}}$ & $1.20^{\mathrm{a}}$ & $1.17^{\mathrm{ab}}$ \\
\hline $\mathbf{F e}_{25} \mathbf{Z n}_{12.5}$ & $0.12^{\mathrm{c}}$ & $0.19^{\mathrm{a}}$ & $0.42^{\mathrm{b}}$ & $0.60^{\mathrm{a}}$ & $0.16^{b}$ & $0.32^{\mathrm{a}}$ & $0.49^{b}$ & $0.69^{\mathrm{a}}$ & $0.76^{\mathrm{ab}}$ & $0.99^{\mathrm{a}}$ & $1.09^{\mathrm{ab}}$ & $1.24^{\mathrm{a}}$ & $1.15^{\mathrm{b}}$ & $1.25^{\mathrm{a}}$ & $1.26^{\mathrm{a}}$ & $1.31^{\mathrm{a}}$ \\
\hline $\mathbf{F e}_{12.5} \mathbf{Z n}_{25}$ & $0.14^{\mathrm{c}}$ & $0.18^{\mathrm{a}}$ & $0.44^{\mathrm{b}}$ & $0.54^{\mathrm{a}}$ & $0.17^{\mathrm{b}}$ & $0.30^{\mathrm{a}}$ & $0.54^{\mathrm{b}}$ & $0.65^{\mathrm{a}}$ & $0.86^{\mathrm{a}}$ & $0.99^{\mathrm{a}}$ & $1.13^{\mathrm{a}}$ & $1.20^{\mathrm{a}}$ & $1.11^{\mathrm{b}}$ & $1.31^{\mathrm{a}}$ & $1.11^{\mathrm{b}}$ & $1.25^{\mathrm{a}}$ \\
\hline $\mathrm{Fe}_{25} \mathbf{Z n}_{25}$ & $0.17^{\mathrm{ab}}$ & $0.20^{\mathrm{a}}$ & $0.46^{\mathrm{b}}$ & $0.65^{\mathrm{a}}$ & $0.20^{b}$ & $0.30^{\mathrm{a}}$ & $0.45^{\mathrm{b}}$ & $0.75^{\mathrm{a}}$ & $0.87^{\mathrm{a}}$ & $0.97^{\mathrm{a}}$ & $1.09^{\mathrm{ab}}$ & $1.26^{\mathrm{a}}$ & $1.12^{\mathrm{b}}$ & $1.28^{\mathrm{a}}$ & $1.18^{\mathrm{ab}}$ & $1.38^{\mathrm{a}}$ \\
\hline Mean & 0.13 & 0.18 & 0.43 & 0.58 & 0.16 & 0.30 & 0.48 & 0.68 & 0.84 & 0.97 & 1.10 & 1.21 & 1.13 & 1.28 & 1.19 & 1.28 \\
\hline \multicolumn{17}{|c|}{ ANOVA: M (Mycorrhizal inoculation), $\mathbf{F}$ (Fe levels), $\mathbf{Z}$ (Zn levels) } \\
\hline $\mathbf{M}$ & \multicolumn{2}{|c|}{$* *$} & \multicolumn{2}{|c|}{$* *$} & \multicolumn{2}{|c|}{$* *$} & \multicolumn{2}{|c|}{$* *$} & \multicolumn{2}{|c|}{$* *$} & \multicolumn{2}{|c|}{$*$} & \multicolumn{2}{|c|}{ ** } & \multicolumn{2}{|c|}{$* *$} \\
\hline $\mathbf{F}$ & \multicolumn{2}{|c|}{$* *$} & \multicolumn{2}{|c|}{$* *$} & \multicolumn{2}{|c|}{$* *$} & \multicolumn{2}{|c|}{$* *$} & \multicolumn{2}{|c|}{$*$} & \multicolumn{2}{|c|}{$*$} & \multicolumn{2}{|c|}{$*$} & \multicolumn{2}{|c|}{$*$} \\
\hline Zn & & & & & & & & ** & & * & & & & & & \\
\hline $\mathbf{M} \times \mathbf{F}$ & & & & & & & & * & & $\mathrm{JS}$ & & & & & & \\
\hline $\mathbf{F} \times \mathbf{Z}$ & & & & & & & & $\mathrm{VS}$ & & $\mathrm{JS}$ & & & & & & \\
\hline $\mathbf{M} \times \mathbf{Z}$ & & & & & & & & $\mathrm{JS}$ & & $\mathrm{JS}$ & & & & & & \\
\hline $\mathbf{M} \times \mathbf{F} \times \mathbf{Z}$ & & & & & & & & * & & $\mathrm{JS}$ & & & & & & \\
\hline
\end{tabular}


Table.3 IAA oxidase activities and super oxide dismutase examined in the shoots of arbuscular mycorrhiza inoculated (AMF+) and non-inoculated (AMF-). The levels of significance for ANOVA, $*=P \leq 0.05 ; * *=P \leq 0.01 ; \mathrm{NS}=$ Not significant.

Means followed by a common letter are not significantly different at the $5 \%$ level by DMRT

\begin{tabular}{|c|c|c|c|c|c|c|c|c|c|c|c|c|c|c|c|c|}
\hline \multirow{4}{*}{ Treatments } & \multicolumn{8}{|c|}{ IAA oxidase activities (Change in OD/min/g) } & \multicolumn{8}{|c|}{ super oxide dismutase $\left(\mathrm{U} \mathrm{g}^{-1}\right)$} \\
\hline & \multicolumn{4}{|c|}{ Calcareous } & \multicolumn{4}{|c|}{ Non-calcareous } & \multicolumn{4}{|c|}{ Calcareous } & \multicolumn{4}{|c|}{ Non-calcareous } \\
\hline & \multicolumn{2}{|c|}{ Sterilized } & \multicolumn{2}{|c|}{ Natural } & \multicolumn{2}{|c|}{ Sterilized } & \multicolumn{2}{|c|}{ Natural } & \multicolumn{2}{|c|}{ Sterilized } & \multicolumn{2}{|c|}{ Natural } & \multicolumn{2}{|c|}{ Sterilized } & \multicolumn{2}{|c|}{ Natural } \\
\hline & $\mathbf{M}^{-}$ & $\mathbf{M}^{+}$ & $\mathbf{M}^{-}$ & $\mathbf{M}^{+}$ & $\mathbf{M}^{-}$ & $\mathbf{M}^{+}$ & $\mathbf{M}^{-}$ & $\mathbf{M}^{+}$ & $\mathbf{M}^{-}$ & $\mathbf{M}^{+}$ & $\mathbf{M}^{-}$ & $\mathbf{M}^{+}$ & $\mathbf{M}^{-}$ & $\mathbf{M}^{+}$ & $\mathbf{M}^{-}$ & $\mathbf{M}^{+}$ \\
\hline $\mathrm{Fe}_{12.5} \mathrm{Zn}_{12.5}$ & $138.1^{\mathrm{c}}$ & $144.4^{\mathrm{b}}$ & $157.4^{\mathrm{bc}}$ & $180.8^{\mathrm{a}}$ & $141.1^{\mathrm{b}}$ & $149.4^{\mathrm{ab}}$ & $151.7^{\mathrm{bc}}$ & $189.7^{\mathrm{a}}$ & $72.5^{\mathrm{ab}}$ & $86.6^{\mathrm{a}}$ & $108.4^{\mathrm{ab}}$ & $124.2^{\mathrm{a}}$ & $88.6^{b}$ & $96.1^{\mathrm{a}}$ & $112.4^{\mathrm{c}}$ & $123.5^{b}$ \\
\hline $\mathrm{Fe}_{25} \mathrm{Zn}_{12.5}$ & $134.3^{\mathrm{c}}$ & $160.2^{\mathrm{a}}$ & $154.4^{\mathrm{bc}}$ & $173.1^{\mathrm{a}}$ & $143.3^{\mathrm{b}}$ & $165.2^{\mathrm{a}}$ & $161.4^{\mathrm{b}}$ & $187.8^{\mathrm{a}}$ & $70.9^{\mathrm{ab}}$ & $86.4^{\mathrm{a}}$ & $109.2^{\mathrm{ab}}$ & $118.5^{\mathrm{a}}$ & $83.5^{\mathrm{b}}$ & $93.2^{\mathrm{ab}}$ & $116.2^{\mathrm{c}}$ & $123.2^{\mathrm{b}}$ \\
\hline $\mathrm{Fe}_{12.5} \mathbf{Z n}_{25}$ & $146.7^{\mathrm{b}}$ & $168.2^{\mathrm{a}}$ & $167.2^{\mathrm{b}}$ & $187.8^{\mathrm{a}}$ & $139.8^{\mathrm{bc}}$ & $171.2^{\mathrm{a}}$ & $163.4^{\mathrm{b}}$ & $195.5^{\mathrm{a}}$ & $81.2^{\mathrm{a}}$ & $89.0^{\mathrm{a}}$ & $113.8^{\mathrm{ab}}$ & $128.7^{\mathrm{a}}$ & $99.0^{\mathrm{a}}$ & $111.3^{\mathrm{a}}$ & $131.8^{\mathrm{a}}$ & $136.4^{\mathrm{a}}$ \\
\hline $\mathrm{Fe}_{25} \mathrm{Zn}_{25}$ & $145.8^{b}$ & $165.7^{\mathrm{a}}$ & $169.8^{b}$ & $182.3^{\mathrm{a}}$ & $140.6^{\mathrm{b}}$ & $166.7^{\mathrm{a}}$ & $167.7^{b}$ & $181.9^{\mathrm{a}}$ & $82.6^{\mathrm{a}}$ & $91.7^{\mathrm{a}}$ & $117.4^{\mathrm{a}}$ & $124.2^{\mathrm{a}}$ & $101.6^{\mathrm{a}}$ & $109.2^{\mathrm{a}}$ & $137.5^{\mathrm{a}}$ & $140.3^{\mathrm{a}}$ \\
\hline Mean & 141.2 & 159.6 & 162.2 & 181.0 & 141.2 & 163.1 & 161.1 & 188.7 & 76.8 & 88.4 & 112.2 & 123.9 & 93.2 & 102.5 & 124.5 & 130.9 \\
\hline \multicolumn{17}{|c|}{ ANOVA: M (Mycorrhizal inoculation), $\mathbf{F}$ (Fe levels), $\mathbf{Z}$ (Zn levels) } \\
\hline $\mathbf{M}$ & \multicolumn{2}{|c|}{$* *$} & \multicolumn{2}{|c|}{ *** } & \multicolumn{2}{|c|}{ *** } & \multicolumn{2}{|c|}{$* *$} & \multicolumn{2}{|c|}{ *** } & \multicolumn{2}{|c|}{ *** } & \multicolumn{2}{|c|}{ ** } & \multicolumn{2}{|c|}{ *** } \\
\hline $\mathbf{F}$ & \multicolumn{2}{|c|}{$* *$} & \multicolumn{2}{|c|}{$*$} & \multicolumn{2}{|c|}{$* *$} & \multicolumn{2}{|c|}{ *** } & \multicolumn{2}{|c|}{ ** } & \multicolumn{2}{|c|}{ *** } & \multicolumn{2}{|c|}{ * } & \multicolumn{2}{|c|}{ * } \\
\hline $\mathbf{Z n}$ & & & 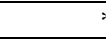 & & & $*$ & & $*$ & & & & * & & & & 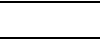 \\
\hline $\mathbf{M} \times \mathbf{F}$ & & & $\overline{\mathrm{N}}$ & & & TS & & $*$ & & & & S & & & & 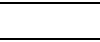 \\
\hline $\mathbf{F} \times \mathbf{Z}$ & & & $\mathrm{N}$ & & & TS & & $*$ & & & & S & & & & \\
\hline $\mathbf{M} \times \mathbf{Z}$ & & & & & & IS & & NS & & & & 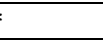 & & & & $S$ \\
\hline $\mathbf{M} \times \mathbf{F} \times \mathbf{Z}$ & & & ? & & & IS & & NS & & & & $\bar{S}$ & & & & $\bar{S}$ \\
\hline
\end{tabular}

Table.4 Catalase activity and Carbonic Anhydrase activity examined in the shoots of arbuscular mycorrhiza inoculated (AMF+) and non-inoculated (AMF-). The levels of significance for ANOVA, $*=P \leq 0.05 ; * *=P \leq 0.01$; NS $=$ Not significant.

Means followed by a common letter are not significantly different at the $5 \%$ level by DMRT

\begin{tabular}{|c|c|c|c|c|c|c|c|c|c|c|c|c|c|c|c|c|}
\hline \multirow{4}{*}{ Treatments } & \multicolumn{8}{|c|}{ Catalase activity $\left(\mu \mathrm{g} \mathrm{H}_{2} \mathrm{O}_{2}\right.$ reduced $\left.\min ^{-1} \mathrm{~g}^{-1}\right)$} & \multicolumn{8}{|c|}{ Carbonic Anhydrase (EU g ${ }^{-1}$ of fresh tissue) } \\
\hline & \multicolumn{4}{|c|}{ Calcareous } & \multicolumn{4}{|c|}{ Non-calcareous } & \multicolumn{4}{|c|}{ Calcareous } & \multicolumn{4}{|c|}{ Non-calcareous } \\
\hline & \multicolumn{2}{|c|}{ Sterilized } & \multicolumn{2}{|c|}{ Natural } & \multicolumn{2}{|c|}{ Sterilized } & \multicolumn{2}{|c|}{ Natural } & \multicolumn{2}{|c|}{ Sterilized } & \multicolumn{2}{|c|}{ Natural } & \multicolumn{2}{|c|}{ Sterilized } & \multicolumn{2}{|c|}{ Natural } \\
\hline & $\mathbf{M}^{-}$ & $\mathbf{M}^{+}$ & $\mathbf{M}^{-}$ & $\mathbf{M}^{+}$ & $\mathbf{M}^{-}$ & $\mathbf{M}^{+}$ & $\mathbf{M}^{-}$ & $\mathbf{M}^{+}$ & $\mathbf{M}^{-}$ & $\mathbf{M}^{+}$ & $\mathbf{M}^{-}$ & $\mathbf{M}^{+}$ & $\mathbf{M}^{-}$ & $\mathbf{M}^{+}$ & $\mathbf{M}^{-}$ & $\mathbf{M}^{+}$ \\
\hline $\mathbf{F e}_{12.5} \mathbf{Z n}_{12.5}$ & $13.2^{\mathrm{b}}$ & $15.5^{\mathrm{ab}}$ & $26.2^{\mathrm{b}}$ & $29.1^{\mathrm{ab}}$ & $16.5^{\mathrm{ab}}$ & $16.8^{\mathrm{ab}}$ & $30.4^{\mathrm{ab}}$ & $32.7^{\mathrm{ab}}$ & $121^{\mathrm{c}}$ & $131^{b}$ & $82^{\mathrm{c}}$ & $86^{\mathrm{c}}$ & $215^{\mathrm{bc}}$ & $241^{b}$ & $184^{\mathrm{c}}$ & $203^{\mathrm{b}}$ \\
\hline $\mathrm{Fe}_{25} \mathrm{Zn}_{12.5}$ & $17.1^{\mathrm{a}}$ & $20.8^{\mathrm{a}}$ & $30.4^{\mathrm{a}}$ & $36.8^{\mathrm{a}}$ & $17.2^{\mathrm{ab}}$ & $20.2^{\mathrm{a}}$ & $33.2^{\mathrm{ab}}$ & $35.4^{\mathrm{a}}$ & $118^{\mathrm{c}}$ & $140^{\mathrm{a}}$ & $77^{\mathrm{C}}$ & $97^{\mathrm{b}}$ & $221^{\mathrm{bc}}$ & $249^{b}$ & $196^{\mathrm{c}}$ & $216^{\mathrm{b}}$ \\
\hline $\mathrm{Fe}_{12.5} \mathrm{Zn}_{25}$ & $16.6^{\mathrm{a}}$ & $18.6^{\mathrm{a}}$ & $28.2^{\mathrm{ab}}$ & $33.7^{\mathrm{a}}$ & $17.7^{\mathrm{ab}}$ & $21.6^{\mathrm{a}}$ & $36.8^{\mathrm{a}}$ & $39.6^{\mathrm{a}}$ & $129^{b}$ & $148^{\mathrm{a}}$ & $98^{\mathrm{b}}$ & $114^{\mathrm{a}}$ & $232^{\mathrm{b}}$ & $291^{\mathrm{a}}$ & $215^{\mathrm{b}}$ & $237^{\mathrm{a}}$ \\
\hline $\mathrm{Fe}_{25} \mathrm{Zn}_{25}$ & $18.4^{\mathrm{a}}$ & $22.4^{\mathrm{a}}$ & $33.5^{\mathrm{a}}$ & $38.7^{\mathrm{a}}$ & $19.4^{\mathrm{a}}$ & $25.8^{\mathrm{a}}$ & $39.5^{\mathrm{a}}$ & $42.4^{\mathrm{a}}$ & $131^{\mathrm{b}}$ & $152^{\mathrm{a}}$ & $103^{\mathrm{ab}}$ & $106^{\mathrm{a}}$ & $236^{b}$ & $290^{\mathrm{a}}$ & $243^{\mathrm{a}}$ & $253^{\mathrm{a}}$ \\
\hline Mean & 16.3 & 19.3 & 29.6 & 34.6 & 17.7 & 21.1 & 35.0 & 37.5 & 125 & 143 & 90 & 101 & 226 & 268 & 210 & 227 \\
\hline \multicolumn{17}{|c|}{ ANOVA: M (Mycorrhizal inoculation), $\mathbf{F}$ (Fe levels), Z (Zn levels) } \\
\hline $\mathbf{M}$ & \multicolumn{2}{|c|}{$* *$} & \multicolumn{2}{|c|}{$* *$} & \multicolumn{2}{|c|}{ *** } & \multicolumn{2}{|c|}{ ** } & \multicolumn{2}{|c|}{ *** } & \multicolumn{2}{|c|}{ *** } & \multicolumn{2}{|c|}{ *** } & \multicolumn{2}{|c|}{ ** } \\
\hline $\mathbf{F}$ & \multicolumn{2}{|c|}{ *** } & \multicolumn{2}{|c|}{$* *$} & \multicolumn{2}{|c|}{$* *$} & \multicolumn{2}{|c|}{ *** } & \multicolumn{2}{|c|}{ NS } & \multicolumn{2}{|c|}{$* *$} & \multicolumn{2}{|c|}{ NS } & \multicolumn{2}{|c|}{ * } \\
\hline Zn & & & & & & & & & & & & & & & & \\
\hline $\mathbf{M} \times \mathbf{F}$ & & & & & & & & & & & & & & & & \\
\hline $\mathbf{F} \times \mathbf{Z}$ & & & & & & & & & & & & & & & & \\
\hline $\mathbf{M} \times \mathbf{Z}$ & & & & & & & & & & & & & & & & \\
\hline $\mathbf{M} \times \mathbf{F} \times \mathbf{Z}$ & & & & & & & & & & & & & & & & \\
\hline
\end{tabular}




\section{Carbonic anhydrase activity}

The carbonic anhydrase activity of M+ shoots was significantly $(P \leq 0.01)$ higher than $\mathrm{M}$ shoots and the increase was exhibited in all the levels of $\mathrm{Fe}$ and $\mathrm{Zn}$ at both stages in calcareous and non-calcareous soil under sterilized (calcareous $M-125 ; M+143$, noncalcareous M- 226; M+ $268 \mathrm{EU} \mathrm{g}^{-1}$ ) and natural (calcareous M- 203; M+ 223, non-calcareous M- 386; M+ $396 \mathrm{EU} \mathrm{g}^{-1}$ ) conditions (Table 4).

\section{Shoot $\mathrm{Zn}$ content}

The $\mathrm{Zn}$ concentration in $\mathrm{M}+$ shoots was significantly $(P \leq 0.01)$ higher than $\mathrm{M}$ - shoots and the increase was exhibited in all the levels of $\mathrm{Fe}$ and $\mathrm{Zn}$ levels in both calcareous and non-calcareous soils regardless of sterilized (calcareous M- 27.0; $\mathrm{M}+34.5$, non-calcareous M- 33.3; M+ $41.9 \mathrm{mg} \mathrm{kg}^{-1}$ ) and natural (calcareous M- 37.4; $\mathrm{M}+45$., non-calcareous M- 47.3; M+ $56.7 \mathrm{mg} \mathrm{kg}^{-1}$ ) conditions (Fig. $1 b)$.

\section{Shoot Fe content}

Mycorrhizal plants had significantly $(P \leq$ 0.01) higher Fe concentration than M- plants irrespective of the $\mathrm{Fe}$ and $\mathrm{Zn}$ levels in both calcareous and non-calcareous soils regardless of sterilized and natural conditions (Fig. 1b). Mycorrhizal inoculation resulted in improving the shoot Fe concentration by 20.0 and $14.3 \%$ in calcareous soil of both sterilized and natural conditions and 10.2 and $8.6 \%$ in non-calcareous soil of sterilized and natural conditions at 75 DAS in comparison to Mshoots.

\section{Total Chlorophyll}

Mycorrhizal symbiosis appears to alter the physiology of plants as a result of enhanced chlorophyll content. As mycorrhizal plants are known to be nutritionally rich and nourished with both macro and micronutrients that may have helped plants to retain higher amounts of chlorophyll content. Subramanian et al., $(1995,1997)$ showed that mycorrhizal inoculated plants had retained higher amount of chlorophyll content under drought conditions. Similar trend of results was also reported under well watered conditions.

\section{Plant metabolic changes}

Increasing attention is being given to the study of the biochemical process involved in the mycorrhization. Important changes were proposed in the plant metabolism after the establishment of symbiosis (Arines et al., 1993; Subramanian and Charest, 1995; Subramanian and Charest, 2004). Some studies also suggested that mycorrhizal infection causes changes in the biochemical constitution of the host plant. The data from this experiment revealed that the physiology of the maize plant was highly affected by the presence of the fungal symbiosis.

The mycorrhizal colonization increased the shoot soluble sugars, proteins and chlorophyll contents irrespective of the fertility gradients. Among the fertility gradients only the treatment with combined application of fertilizers with farmyard manure was significantly notable. Similarly the findings of Tejada and Gonzalez (2006) who observed highest values of these parameters with combined application of inorganic fertilizers and crushed cotton gin compost and the lowest values in control plots.

\section{Soluble Proteins}

In this study, soluble proteins concentrations in AM- inoculated maize roots increased was higher than uninoculated plants. These proteins may play a role in acquisition and assimilation of $\mathrm{Zn}$ which is yet to be explored. Further, $\mathrm{Zn}$ nutrition enhanced the 
accumulation of soluble proteins in mycorrhizal plants which may be due to the fact that $\mathrm{Zn}$ is responsible for the synthesis of amino acids such as tryptophan and asparagin (Dumas et al., 1990; Simoneau et al., 1994).

Krishna and Bagyaraj (1983) reported that total sugar and protein content of mycorrhizal groundnut plants were higher throughout the growth period than the non mycorrhizal plants. Subramainan et al., (1995) also observed that the mycorrhizal inoculation enabled the plants to retain considerable amount of sugars and proteins especially in drought sensitive cultivar. Similarly, Wright et al., (1996) also reported the amount of sugars in the leaves of mycorrhizal plants was significantly different to that in the leaves of non-mycorrhizal plants at any stage during experiment; the amount of soluble protein was higher in mycorrhizal compared to nonmycorrhizal plants. This may be because mycorrhizal fungi increased the uptake of $\mathrm{P}$ and they may also increase the synthesis of carbon compounds (Demir, 2004). The data on soluble protein of this experiment is in line with the above findings.

The increase in soluble protein concentrations in mycorrhizal inoculated maize plants corresponded with earlier reports (Mathur and Vyas, 1996; Subramanian and Charest, 1998). Arines et al., (1993) also detected two to six fold increases in soluble proteins in mycorrhizal clover roots. Zinc nutrition also enhanced the accumulation of soluble proteins in mycorrhizal plants which may be due to the fact that $\mathrm{Zn}$ is responsible for the synthesis of amino acids such as tryptophan and asparagine.

\section{Changes in anti-oxidant enzyme activities}

Mycorrhizal symbiosis causes important changes in plant metabolism and growth (Arines et al., 1994), although very little is known of the biochemical mechanisms involved in this mycorrhizal association. The shoot / root ratio is of importance when studying the degree of AM fungi effectiveness on the host plant (Tobar et al., 1994). In the present work, the results obtained showed increased anti-oxidant enzyme activities (peroxidase, polyphenol oxidase and IAA oxidase) besides increased acid phosphatase, soluble proteins and nutritional status due to inoculation of arbuscular mycorrhizal (AM) fungus (Glomus intraradices) in maize while compared to non-mycorrhizal plants. The activities of enzymes and nutrient concentration in inoculated and uninoculated maize plants increased with incremental levels of $\mathrm{Zn}$ application but the values were consistently higher for inoculated treatments. This work support the view that increased antioxidant enzyme activities could be involved, in the beneficial effects of mycorrhizal colonization.

Plants grown in calcareous soil are exposed to wide range of nutrient depressed especially $\mathrm{Fe}$ and $\mathrm{Zn}$. Management of $\mathrm{Ca}$ induced micronutrient deficiencies very difficult to correct due to fact that the addition of fertilizers will get fixed or converted into insoluble form. The micronutrient deficient plants are often produce ROS that causes lipid peroxidation in cell wall and associated impacts on photosynthesis. This study clearly demonstrated that mycorrhizal inoculated plants are less stressed by micronutrient deficiencies as indicated by the enhanced activities of anti-oxidant enzyme systems. Subramanian et al., (2011) showed that mycorrhizal symbiosis triggers anti-oxidant system that effectively quench the ROS and protect the plants from oxidative damage. These data in conjunction with literature published is quite evident that mycorrhizal symbiosis can help the plants withstand micronutrient deficiencies as a result of antioxidant enzyme activities. 
Mycorrhizal fungi are known to enhance water absorption by plants grown under water- deficit conditions, owing to altered root morphology or contributions by soil hyphae (Auge 2001). The enzymes superoxide dismutases (SOD), and catalases (CAT) and peroxidases are involved in the detoxification of $\left(\mathrm{O}_{2}{ }^{-}\right)$, hydrogen peroxide $\left(\mathrm{H}_{2} \mathrm{O}_{2}\right)$, respectively thereby preventing the formation of $\left(\mathrm{OH}^{-}\right)$hydroxyl radicals (Jimenez et al., 1997).In this study, the peroxidase activity of AM fungus (Glomus intraradices) inoculated maize plants increased with incremental levels of zinc application and the results are in agreement with the findings of Ghorbani et al., (2004) who have reported enhanced peroxidase activity of AM-fungus inoculated soybean.

Poly phenol oxidase (PPO) activities have frequently been suggested to participate in plant defence against pests and pathogens (Thipyapong et al., 1995, 1997). In this study, PPO was found to be abundant (Glomus intraradices) inoculated plants with the interaction effect of zinc at various levels compared to other AM fungus species inoculated plants. There are reports pointing out that PPO is prominent amongst the defence proteins induced in crop plants (Constabel et al., 1995; Constabel and Ryan, 1998). There are also reports that inoculation with AM fungi may induce an increase in PPO activity and accumulation of defense proteins (Peter, 1989). Mathur and Vyas (1996) showed a considerable increase in PPO activity in AM fungus (Glomus fasciculatum) inoculated Ziziphus xylopyrus

IAA oxidase activity measured as $\mathrm{mg}$ of unoxidised auxin increased with mycorrhizal colonization or $\mathrm{Zn}$ nutrition. Auxins are widespread in nature and are produced by plants and mycorrhizal fungi (Slankis, 1974). There is a close association between $\mathrm{Zn}$ nutrition and accumulation of auxin (Tsui,
1948). It is observed in our study that mycorrhizal colonization improves the level of auxin in host plants in association with incremental level of zinc nutrition. As mycorrhizal symbiosis assists in improving $\mathrm{Zn}$ status and auxin levels of the host plant, the dry matter production of inoculated plants were consistently higher despite the height of the plants were similar (data not shown).

\section{Nutrient Status in Plants}

In the present study mycorrhizal inoculation had significantly increased the micronutrient content and uptake by maize plants over the non mycorrhizal maize plants in all levels of $\mathrm{Fe}$ and $\mathrm{Zn}$ in calcareous and non-calcareous soil regardless of sterilized or natural conditions. The results obtained by earlier workers on plant micronutrient content and its uptake on mycorrhizal inoculation are discussed below. Though uptake of micronutrient usually dominates consideration of the mycorrhizal association, it has become increasingly apparent that mycorrhiza can be important in the uptake of other nutrients by the host plant. Uptake of $\mathrm{Zn}, \mathrm{Cu}, \mathrm{Fe}, \mathrm{N}, \mathrm{K}, \mathrm{Ca}$ and $\mathrm{Mg}$ has been reported as being enhanced (Smith and Read, 1997; Clark and Zeto, 2000).

Mycorrhizal fungus inoculated plants were nutritionally rich, which resulted in higher biomass production and $\mathrm{Zn}$ uptake even under $\mathrm{Zn}$ deficient conditions. The external mycelium of mycorrhizal fungus proliferates extensively beyond the rhizosphere capable of translocating immobile ions such as $\mathrm{PO}^{4-}$ and $\mathrm{Zn}^{2+}$ (Li et al., 1991; Jakobsen et al., 1992). The response to mycorrhizal inoculation was more pronounced under deficient levels of $\mathrm{Zn}$ than sufficient levels indicating that mycorrhizal association is more beneficial when the plants are exposed to $\mathrm{Zn}$ deficiency. The effectiveness of mycorrhizal root absorption is increased by external hyphae 
(Bürkert and Robson, 1994). Under conditions of low micronutrient level, arbuscular mycorrhizal fungus hyphae enhanced uptake of $\mathrm{Fe}$, most likely by improved scavenging of this element. The results are in agreement with those of Clark and Zeto (1996), who found that mycorrhizae improved $\mathrm{Fe}$ uptake in maize grown in $\mathrm{Fe}$ deficient soils. Hamel et al., (2000) also recorded increase in micronutrient content due to inoculation of $G$. intraradices in tomato plants. Uptake of nutrients by plants not only depends on the availability of nutrients in soil solution, but also on the effectiveness of root systems for absorption.

\section{Acknowledgement}

The authors wish to thank the Science and Engineering Research Board (SERB), Department of Science and Technology, New Delhi, India for providing financial support to carry out this research program under the scheme (YSS/2015/000619).

\section{References}

Abbott L K, Robson AD, 1984. The effect of mycorrhizas on plant growth p113 - 130 . In: VA mycorrhizae. Powell CL, Bagyaraj DJ eds. Boca Raton, Florida: CRC Press.

Arines J, Palma JM, Viarino A, 1993. Comparison of protein pattern in non mycorrhizal and VA mycorrhizal roots of red clover. New Phytol 123: 763-768

Arines J, Quintela M, Vilarino A, Palma JM, 1994. Protein pattern and superoxide dismutase activity in non-mycorrhizal and arbuscular mycorrhizal Pisum sativum L. plants. Plant Soil 166: 37-45

Auge RM, 2001. Water relations, drought and vesicular- arbuscular mycorrhizal symbiosis. Mycorrhiza 11: 3- 42

Augé RM, 2001. Water relations, drought and vesicular arbuscular mycorrhizal symbiosis. Mycorrhiza 11: 3-42.

Beyer WF, Fridovich I, 1987. Assaying for superoxide dismutase activity: some large consequences of minor changes in conditions. Anal Biochem 161: 559-566

Beyer WF, Fridovich I, 1987. Assaying for superoxide dismutase activity: some large consequences of minor changes in conditions. Anal Biochem 161: 559-566

Bonfante P, Perotto S, 1995. Strategies of arbuscular mycorrhizal fungi when infecting host plants. New Phytol 130: 3 21.

Bruinsma J, 1963. The quantitative analysis of chlorophylls $a$ and $b$ in plant extracts. Photochem. Photobio 2: 241-249.

Clark RB, Zeto SK, 1996. Growth and root colonization of mycorrhizal maize grown on acid and alkaline soil. Soil Biol Biochem 28: 1505-1511.

Clark RB, Zeto SK, 2000. Mineral acquisition by arbuscular mycorrhizal plants. J Plant Nutr 23: 867-902.

Constabel CP, Bergey DR, Ryan CA, 1995. Systemin activates synthesis of woundinducible tomato leaf polyphenol oxidase via the octadecanoid defense signaling pathway. Proc National Academy Sci 92: $407-411$.

Constabel CP, Ryan CA, 1998. A survey of wound - and methyl jasmonate - induced leaf polyphenol oxidase in crop plants. Phytochemistry 47: $507-511$.

Dinkelaker B, Marschner H, 1992: In vivo demonstration of acid phosphatase activity in the rhizosphere of soil grown plants. Plant soil 144: 199- 205.

Dodd JC, Burton CC, Jeffries P. 1987. Phosphatase activity associated with the roots and the rhizosphere of plants infected with vesicular - arbuscular mycorrhizal fungi. New Phytol 107: 163 -172 .

Dumas E, Perason GV, Gianinazzis, 1990. Production of new soluble protein during endomycorrhizae formation. Agric Ecosyst Environ 29: 111 - 114

Faber BA, Zasoski RJ, Burau RG, Uriu K, 1990. Zinc uptake by corn affected by vesicular-arbuscular mycorrhizae. Plant Soil 129: $121-131$. 
Ghorbanli M, Ebrahimzadeh H, Sharifi M, 2004. Effects of $\mathrm{NaCl}$ and mycorrhizal fungi on antioxidative enzymes in soybean. Biologia Plantarum 48: 575-581

Gibbson TS, Leece DR, 1981. Estimation of physiologically active $\mathrm{Zn}$ in maize by biochemical assay. Plant Soil 63: 395-406

Hamel C, Liu A, Hamilton RI, Ma BL, Smith $\mathrm{DL}, 2000$. Acquisition of $\mathrm{Cu}, \mathrm{Zn}, \mathrm{Mn}$ and Fe by mycorrhizal maize (Zea mays L.) grown in soil at different $\mathrm{P}$ and micronutrient levels. Mycorrhiza 9: 331336.

Jakobsen I, Abbott LK, Robson AD, 1992. External hyphae of vesicular-arbuscular mycorrhizal fungi associated with Trifolium subterraneum L. 1. Spread of hyphae and phosphorus inflow into roots. New Phytol 120: 371-380.

Jimenez A, JHernandez A, del Rio LA, Sevilla F, 1997. Evidence for the presence of the ascorbate - glutathione cycle in mitochondria and peroxisomes of pea leaves. Plant physiol 114: 275 - 284.

Krishna KR, Bagyaraj DJ, 1983. Changes in the free amino nitrogen and protein fractions of groundnuts caused by inoculation with mycorrhiza. Ann Bot, 51: 399-401.

Li XL, Marschner H, Romheld V, 1991. Acquisition of phosphorus and copper by VA-mycorhizal hyphae and root to shoot transport in white clover. Plant Soil 136: 49-57.

Lobo MG, Cano MP, 1998. Preservation of hermaphrodite and female papaya fruits (Carica papaya L.,) by freezing: physical, physico chemical and sensorial aspects. Eur Food Res Toxicol 206: 343-349

Lowry OH, Rosebrough NJ, Farr AL, Randall RJ, 1951. Protein measurement with the folin phenol reagent. J Biol Chem 193: 265-75

Magnoli CE, Saenz MA, Chiacchiera SM, Dalcero AM, 1999. Natural occurrence of Fusarium species and fumonisin production by toxigenic strains isolated from poultry feeds in Argentina. Mycopathologia 145: 35 - 41 .

Marschner H, 1986. Mineral Nutrition of
Higher Plants. Academic Press, New york Mathur N, Vyas A, 1996. Biochemical changes in Ziziphus xylopyrus by VA mycorrhizae. Bot Bull Acad Sin 37:209212

Morandi D, Bailey JA, Gianinazzi-Pearson V, 1984. Isoflavonoid accumulation in soybean roots infected with vesiculararbuscular mycorrhizae fungi. Physiol Plant Pathol 24: 357 - 364.

Palma JM. Longa MA, Del Rio LA, Arines J, 1993. Superoxide dismutase in vesicular arbuscular-mycorrhizal red clover plants. Physiol Plant 87: 77 - 83.

Peter MG, 1989. Chemical modifications of biopolymers by quinines and quinine methides Angewandte Chemie, International edition in English 28: 555 570.

Porcel R, Barea JM, Ruiz-Lozano JM, 2003. Antioxidant activities in mycorrhizal soybean plants and their possible relationship to the process of nodule senescence. New Phytol 157: 135 - 143.

Requena N, Perez-Solis E, Azcon-Aguilar C, Jeffries P, Barea JM, 2001. Management of indigenous plant-microbe symbioses aids restoration of desertified ecosystems. Appl Environ Microb 67: 495 - 498.

Ruiz-Lozano JM, Azcon R, Palma JM, 1996. Superoxide dismutase activity in arbuscular mycorrhizal Lactuca sativa plants subjected to drought stress. New Phytol 134: 327-333

Sadasivam S, Manickam A, 1996. Biochemical Methods. New Age International, New Delhi, India pp. 112-113.

Scandalios JG, 1993. Oxygen stress and Superoxide dismutases. Plant Physiol 101: 7 - 12 .

Simoneau P, Louisy - Louis N, Plenchette C, Strullu DG, 1994. Accumulation of new polypeptides in Ri T- DNA- transformed roots of tomato during development of arbuscular mycorrhiza. Appl Environ Microbiol 6: 1810 - 1813.

Slankis V, 1974. Soil factors influencing formation of mycorrhizae. Annual Review of Phytopathology 12: 437-457. 
Smith SE, Read DJ, 1997. Vesicular-Arbuscular Mycorrhizas. In: Mycorrhizal symbiosis. $\left(\mathrm{II}^{\mathrm{ed}}\right)$ Academic Press, New York, USA pp. 9-126.

Subramanian KS, Charest C, 1995. Influence of arbuscular mycorrhizae on the metabolism of maize under drought stress. Mycorrhiza 5: 273-278.

Subramanian KS, Charest C, 1998. Arbuscular mycorrhizae and nitrogen assimilation in maize after drought and recovery. Physiol Plant 102: 285-296

Subramanian KS, Charest C, 2004. Arbuscular mycorrhizal symbiosis improves host plant drought tolerance. Indian $\mathbf{J}$ Agric Res Manage 3: 1-10.

Subramanian KS, Charest C, Dwyer LM, Hamilton RI, 1995. Arbuscular mycorrhizas and water relations in maize under drought stress at tasselling. New Phytol 129: 643-650.

Subramanian KS, Charest C, Dwyer LM, Hamilton RI, 1997. Effects of mycorrhizas on leaf water potential, sugar and $\mathrm{P}$ contents during and after recovery of maize. Can $\mathbf{J}$ Bot 75: 1582-1591.

Subramanian KS, Tenshia J. S, Jayalakshmi K, Ramachandran V, 2011. Antioxidant enzyme activities in arbuscular mycorrhizal (Glomus intraradices) fungus inoculated and non-inoculated maize plants under zinc deficiency. Indian J Microbiol 51(1): 37-43

Sylvia DM, Hammond LC, Bennet JM, Hass JH Linda SB, 1993. Field response of maize to a VAM fungus and water management. Agron J 85: 193-198
Tarafdar JC Jungk A, 1987. Phosphatase activity in the rhizosphere and its relation to the depletion of soil organic phosphorus. Biol Fertil Soils 3: 199 204.

Tejada M, Gonzalez JL, 2006. Crushed cotton gin compost on soil biological properties and rice yield. Europ J Agron, 25: 22-29.

Thipyapong P, Hunt MD, Steffens JC, 1995. Systemic wound induction of potato (Solanum tuberosum) polyphenol oxidase. Phytochem 40: 673 - 676.

Thipyapong P, Joel DM, Steffens JC, 1997. Differential expression and turnover of the tomato polyphenol oxidase gene family during vegetative and reproductive development. Plant Physiol 113: 707 718.

Tobar RM, Azcon R, Barea JM, 1994. The improvement of plant $\mathrm{N}$ acquisition from an ammonium- treated, drought - stressed soil by the fungal symbiont in arbuscular mycorrhizae. Mycorrhiza 4: $105-108$.

Tsui C, 1948. The role of zinc in auxin synthesis in the tomato plant, Amer J Bot 35: $172-179$

Woodbury W, Spencer AK, Stahman MA, 1971. An improved procedure for using ferricyanide for detecting catalase isozymes, Anal Biochem 44: 301-305

Wright SF, Franke-Snyder M, Morton J, Upadhyaya A, 1996. Time-course study and partial characterization of a protein on hyphae of arbuscular mycorrhizal fungi during active colonization of roots. Plant Soil 181: 193-203.

\section{How to cite this article:}

Natarajan Balakrishnan and Kizhareal S. Subramanian. 2017. Arbuscular mycorrhizal fungus inoculation on antioxidant enzyme activities in maize plants at different levels of $\mathrm{Fe}$ and $\mathrm{Zn}$ fertilization. Int.J.Curr.Microbiol.App.Sci. 6(6): 1754-1768.

doi: https://doi.org/10.20546/ijcmas.2017.606.204 